\title{
高温固体電解質型燃料電池の一貫作成を目指した ハイブリッドプラズマ溶射法開発
}

\author{
浜 谷 秀 樹* 熊 岡尚** \\ 八 幡 稔 文** 吉 田 豊 信***
}

J. Japan Inst. Metals, Vol. 55, No. 11 (1991), pp. 1240-1248

An Integrated Fabrication Process for Solid Oxide Fuel Cells

Using Hybrid Plasma Spraying

\author{
Hideki Hamatani*, Hisashi Kumaoka**, \\ Toshifumi Yahata** and Toyonobu Yoshida***
}

This study was aimed at developing integrated fabrication process for solid oxide cells (SOFC) with radio-frequency plasma spraying (RFPS) and/or hybrid plasma spraying (HYPS). Fundamental studies concerning particle velocity and deformation of $\mathrm{ZrO}_{2}-12 \mathrm{wt} \% \mathrm{Y}_{2} \mathrm{O}_{3}(\mathrm{YSZ})$ showed that even the lower particle velocities in RFPS $(20 \mathrm{~m} / \mathrm{s})$ and HYPS $(40-70 \mathrm{~m} / \mathrm{s})$ compared with the case in direct current plasma spraying $(\sim 200 \mathrm{~m} / \mathrm{s})$, were found to be sufficient for the deformation of impinging molten YSZ particles on the substrate. RFPS, however, imposed a severe limitation on the substrate position because it led to short flying distance of molten particles. In this respect, HYPS was considered to be superior than RFPS. Actually, using $75 \mu \mathrm{m} \mathrm{YSZ} \mathrm{powder,} \mathrm{HYPS} \mathrm{made} \mathrm{it} \mathrm{possible} \mathrm{to} \mathrm{get} \mathrm{not} \mathrm{only} \mathrm{dense} \mathrm{YSZ} \mathrm{coating} \mathrm{with} \mathrm{the} \mathrm{relative}$ density higher than $98 \%$ but also good gas permeability lower than $5.7 \times 10^{-7} \mathrm{~cm}^{4} / \mathrm{g} \cdot \mathrm{s}\left(2500 \mathrm{mmH}_{2} \mathrm{O}\right)$. Moreover, porous $\mathrm{NiO}$ and chemical stable $\mathrm{LaCoO}_{3}$ as electrodes could be prepared by $\mathrm{Ar}-\mathrm{O}_{2} \mathrm{HYPS}$. Though the cell performance had not been investigated yet, these experimental results have proved that HYPS must be a strong candidate to open new aspects of the production process for SOFC, especially, from economical and engineering points of view.

(Received March 22, 1991)

Keywords: radio-frequency plasma, hybrid plasma, plasma spraying, yttria stabilized zirconia, perovskite, solid oxide fuel cell

\section{I. 序論}

過酷な使用条件下での信頼性・安全性確保の観点から， 材料開発の中でューティング技術に寄せられる期待は大き い. 昨今の研究成果を眺めてもセラミックスに対する評価 は高まり，金属との接合による新素材開発も注目を浴びる よらになってきて拈り，この分野からのコーティング技術 へのニーズも高まってきた．しかしセラミックスは金属と 比較して脆性面に問題があり，構造材としてではなく，機 能材としての利用の工業化が先行している. 特にコーティ ング技術の開発が精力的に行われて括り，CVD法・PVD 法・溶射法などは代表的な技術といえよう.

なかでも溶射法は他の手法と比較して堆積速度が $10^{-2}$ $\mathrm{mm} / \mathrm{s}$ と数桁速く, また原料の歩留の点でも有利性を示し ている．更に基板の形状や種類における制約も少ないた め, 発電機, ディーゼルェンジンの耐熱性向上, ボイラー 等の耐熱, 耐腐食, 耐摩耗性の向上抏よび補修作業の軽 減，また航空機用ジェットェンジンに拈ける耐摩耗性向上 などを目的とし，熱機関を中心に広く応用されている。こ の場合, 皮膜に形成される多数の空孔・亀裂はそれ程悪影 響を及ぼさないため，通常の直流(DC) プラズマ溶射法に より形成された皮膜でも十分な成果をあげている.

新たな応用分野としては, 高温固体電解質型然料電池 (SOFC)への適用が挙げられる. SOFC は電解質・空気極 ·燃料極の三層構造 (Fig. 1)から構成されている. 電解質 は内部抵抗低減のため緻密化を，一方，電極は反応効率向 上のため多孔質化を要求している. 円筒型, 平板型など数

* 東京大学大学院生, 現在 : 新日本製鉄(侏)中央研究本部第二技術研究所 (Graduate Student, The University of Tokyo, Tokyo. Present address: R \& D Laboratories-II, Nippon Steel Corporation, Sagamihara)

** 東京大学大学院生 (Graduate Student, The University of Tokyo, Tokyo)

*** 東京大学工学部金属工学科 (Department of Metallurgy, Faculty of Engineering, The University of Tokyo, Tokyo) 


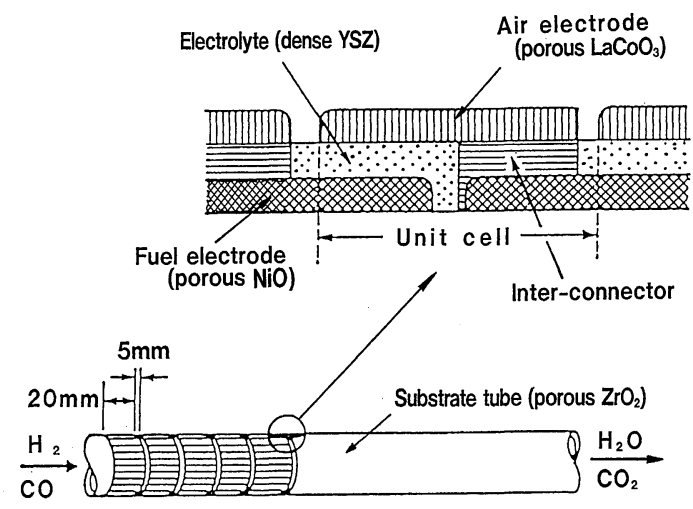

Fig. 1 Schematic diagram of SOFC.

種類の形状が考案されてきたが，その中でも円筒型形状の ものが高い効率・大面積化が可能なことから現在開発が最 む精力的に進められている. 円筒基板使用に際してもプラ ズマ溶射法は先述の理由から最も有効な手法の一つである と考えられるが，電解質材料である $\mathrm{Y}_{2} \mathrm{O}_{3}$ 安定化 $\mathrm{ZrO}_{2}$ (YSZ)の緻密皮膜形成や空気極材料であるランタン系ペロ ブスカイト型酸化物の安定皮膜形成に DC プラズマ溶射法 を用いることは極めて困難である．すなわち DC プラズマ は容積む小さく $(\phi 5 \mathrm{~mm} \times 100 \mathrm{~mm})$, プラズマ内で極めて 急激な温度勾配 $\left(10^{6} \mathrm{~K} / \mathrm{m}\right) \cdot$ 速度勾配 $\left(10^{4} \mathrm{~m} / \mathrm{s} / \mathrm{m}\right)$ を示す ため，供給した原料粉末の均一かつ十分な溶融は原理的に 不可能である．そのため多孔質な皮膜が形成されることと なる、しかしながら，本研究室で開発した高周波 $(\mathrm{RF})$ プ ラズマ溶射法はこの問題点を克服したプロセスとなってお り，実用金属の $\mathrm{Ni} \cdot \mathrm{Mo}$ やセラミックスの $\mathrm{Al}_{2} \mathrm{O}_{3}$ の緻密皮 膜形成も可能としている(1)(2)。また無電極放電のために自 由な雾囲気制御も行えるのが利点となっている. 更に同プ ロセスは DC プラズマ溶射法と比較して大粒径粒子を使用 するため接合に関しても有利性を示し，接合強度の向上も 確認されている(2)(3)。乙かし， $\mathrm{ZrO}_{2}$ 系セラミックスは高 融点・高放射率物質であるため，RF プラズマの持つ低流 速性により，条件によっては溶融粒子が基板到達前に凝固 してしまう場合もあることが現在までの研究で明らかとな った ${ }^{(4)}$.この問題点を克服するため $\mathrm{RF}$ プラズマに DC プ ラズマを重畳させたハイブリッド(HY) プラズマ溶射法を 開発することが重要となってきた．HY プラズマ溶射法は $\mathrm{RF}$ プラズマ溶射法の利点に加光，飛行粒子の速度をある 程度制御できるという利点も併せるつ. 本手法を用いるこ とにより，溶射に招いて最も困難であると考えられる $\mathrm{ZrO}_{2}$ 系の緻密皮膜形成を可能とするならば，液相を含有 するかなりの材料の膜質も自由に制御形成できることとな り，溶射法の新しい応用分野拡大に大きな意義を持つこと になる。また，雾囲気制御が特に重要であるぺロブスカイ 卜型酸化物のように，高温で化学的に不安定な物質の溶射 による安定な皮膜形成も可能となる.
本研究では，以上の問題点を背景に RF および $\mathrm{HY}$ プ ラズマ溶射法を用い, $\mathrm{ZrO}_{2}$ を代表として高融点物質皮膜 の緻密皮膜形成，および $\mathrm{LaCoO}_{3}$ を代表として高温で化学 的に不安定な物質の安定皮膜形成に関する検討を行った。 更に SOFC の本法による一貫製造に関する可能性につい ても検討を行った。

\section{II. 溶射実験・結果}

\section{1. 実験装置・方法}

実験装置は $\mathrm{RF}$ 预よび $\mathrm{DC}$ 電源, プラズマトーチ，チャ ンバー，粉体供給装置，执よびガス系からなっている．主 に実験に用いた HY プラズマトーチ(Fig. 2)は RF プラズ マ発生用の 3 巻コイル, 水冷した 2 重石英管, 回転・半 径方向への $\mathrm{Ar}, \mathrm{H}_{2}\left(\mathrm{O}_{2}\right)$ ガス供給管からなる RF プラズマ 発生部と，Arをキャリアーガスとした粉体導入系を備兄 た従来の DC ガンから構成されている. RF プラズマ発生 用電源は $4 \mathrm{MHz}$ ・最大プレート入力值 $50 \mathrm{~kW} て ゙ あ り$, $\mathrm{DC}$ プラズマ用電源は最大入力 $30 \mathrm{~kW}$ で，最大電流值は $500 \mathrm{~A}$ である. 溶射粉末は DC ガンの装入角度 $45^{\circ}$ のノズ ルから供給する．以後基板位置 $(L)$ はトーチ出口と基板間 の距離で示す.

飛行粒子速度はチャンバー前扉の $75 \mathrm{~cm} \times 28 \mathrm{~cm}$ の空か ら流しカメラ写真撮影法により測定した．Fig. 3 は今回 実験に主に用いた装置図を示す．基板にはSUS304 平板 拈よびCSZ(Calcia Stabilized Zirconia) 円筒管を用いた。 基板ホルダーとしてはプラズマ直下での回転型，各種セン

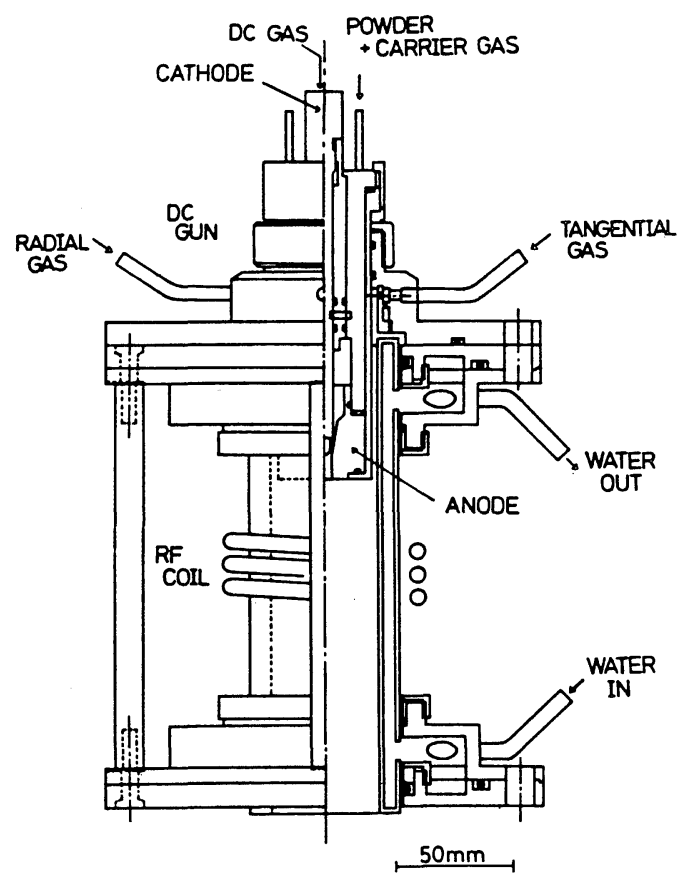

Fig. 2 Schematic diagram of hybrid plasma torch. 


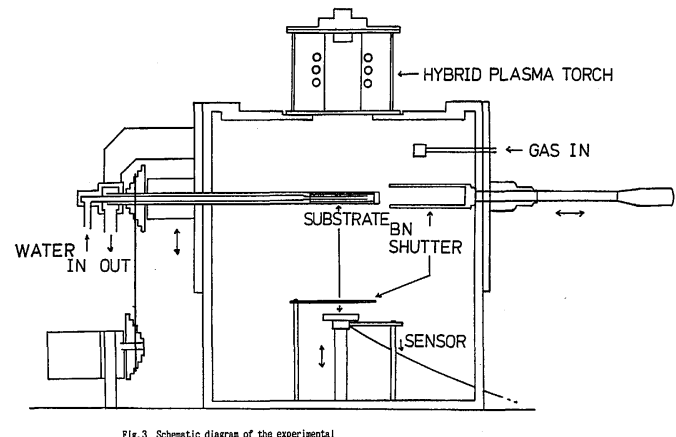

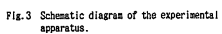

Fig. 3 Schematic diagram of the experimental apparatus.

サー測定が可能なスリコギ運動型, 円筒基板用回転型の 3 種が装備されている. 基板ホルダーは水冷されており, 回転数・基板位置は可変であり, かつプラズマから基板へ の熱影響軽減, 堆積領域制御のためのシャッターを設置し ている.またプラズマ尾炎部と基板間にガスを供給するこ とにより, 熱影響, 粒子溶融状態, 雲团気制御をも可能と した. 粒子変形度試験から粒子の熱履歷を検討し, 得られ た皮膜の膜質評価は SEM 観察，アルキメデス法による密 度測定, XRD 分析, LECO 分析により行った.

な扮使用した原料粉は $\mathrm{ZrO}_{2}-12 \mathrm{wt} \% \mathrm{Y}_{2} \mathrm{O}_{3}$ (公称)の溶融 粉砕粉を 37〜 $105 \mu \mathrm{m}$ の範囲で 3 種類に分級したもの, 市販の $40 \sim 100 \mu \mathrm{m}$ の $\mathrm{NiO}$ 拉よび $25 \sim 88 \mu \mathrm{m}$ の $\mathrm{LaCoO}_{3}$ で, 後者の 2 つは数 $\mu \mathrm{m}$ の粒子から成る凝集粉である.

\section{2. 実験結果}

\section{（1）粒子の速度測定および変形度試験}

$\mathrm{RF}$ 拈よび HY プラズマ溶射法での粒子速度を評価する ため高速流しカメラ写真測定法により $L=100 \mathrm{~mm}$ に和け る飛行粒子の速度測定を行った。ここでは測定結果の平均 值を各実験条件の粒子速度と定義した．RF プラズマ溶射 法に拈ける粒子速度は，粒径依存性を注とんど示さず Fig. 4 のように約 $20 \mathrm{~m} / \mathrm{s}$ とほぼ一定となった。これに対 し HY 溶射法では DC 入力の影響を受け $45 \sim 70 \mathrm{~m} / \mathrm{s}$ の間 で粒速が変化した(Fig. 5)。このような, Hybrid 化によ る粒子速度制御範囲の拡大は, 本法のさらに広い応用範囲 の拡大を示唆するものである.

変形度試験はプラズマ尾炎部で基板を 1 回転させる間 に溶射される粒子の変形度を SEM 観察することにより測 定したものである(1)(2)。ここで出発粉体の直径を $d$, 変形 後の直径を $D$ としこの比 $D / d$ を変形度と定義した。平均 粒径 $75 \mu \mathrm{m}$ の YSZ の变形度と各值に関する SEM 像の関 係を Fig. 6 亿表す．粒子が飛行中に蒸発し基板到達時に はすでに凝固している場合は $D / d<1$. 粒子がほとんど溶 融していないか，または蒸発温度には達しないが基板衝突 時にはすでに凝固している場合は $D / d=1$. 粒子はある程

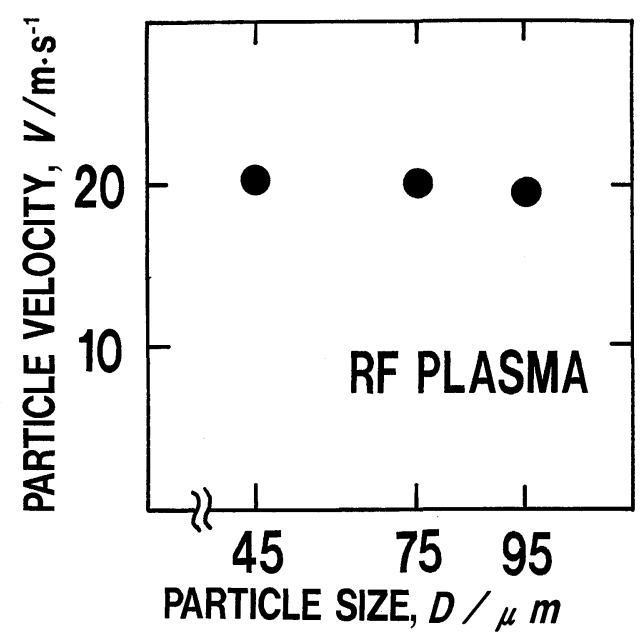

Fig. 4 Particle velocity for the case of RF plasma spraying.

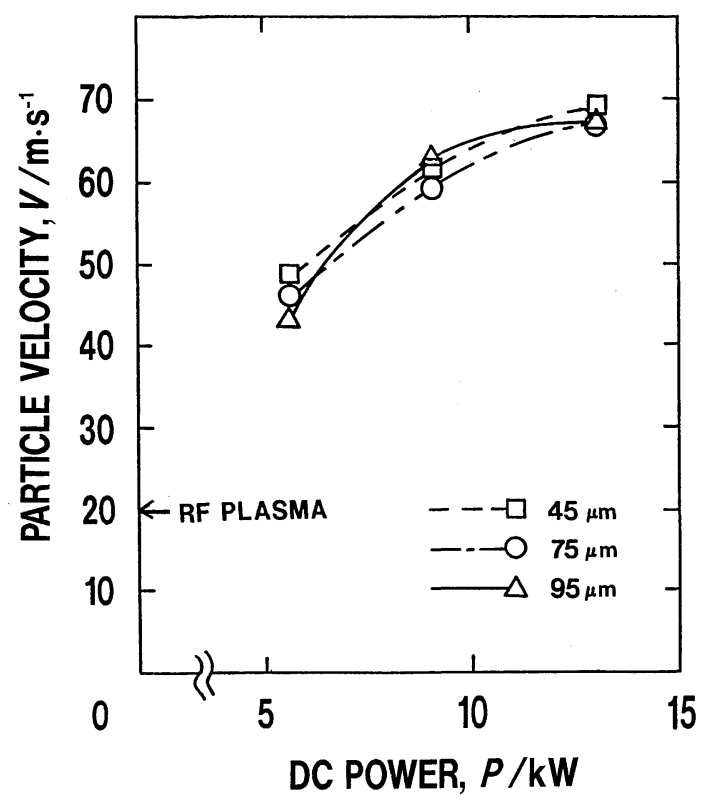

Fig. 5 The effect of DC input power on the particle velocity.

度高温飞達するが十分な变形が得られる温度に達しない場 合は $D / d=2$ となり, 溶融温度が高く十分な変形が得られ る場合は $D / d=3$ となる. しかし $D / d=4$ の時は溶融温度 が高すぎ，基板衝突時に飛洙が生じるため，膜質劣化を引 き起こするのと考光られる。つまり YSZ の高密度均質皮 膜の最適の $D / d$ の值は拉よそ 3 であることが判明した。

$\mathrm{RF}$ プラズマと HY プラズマ溶射法による $D / d$ 測定結 果をFig. 7 亿示す. $D / d$ はY プラズマ溶射法のほうが $\mathrm{RF}$ プラズマ溶射よりも 1 程度大きく，溶射に適した 2.5〜3になっており，基板位置の影響が小さいことが特 

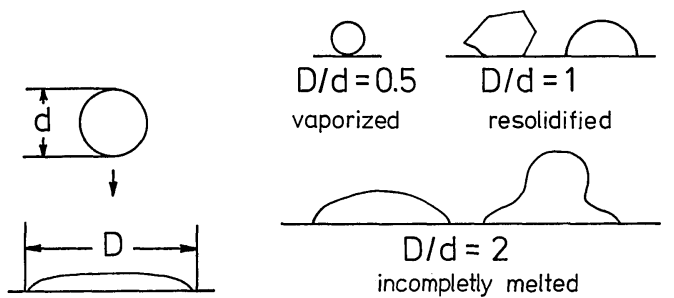

$\mathrm{D} / \mathrm{d}=2$

incompletly melted
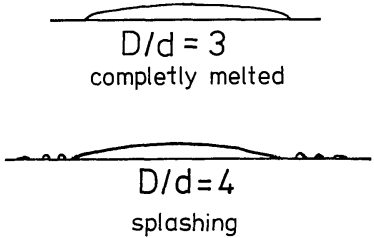

Fig. 6 The relation between the value of $(D / d)$ and deformation patterns.

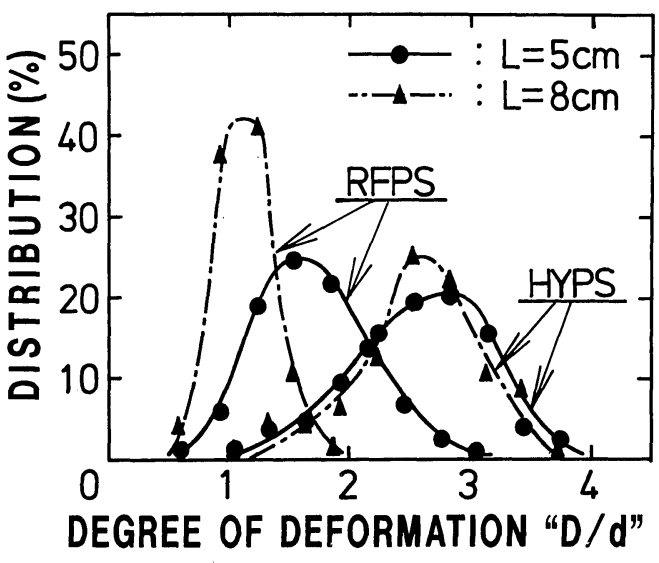

Fig. 7 The effect of spraying distance on the deformation parameter $(D / d)$ for the cases of $\mathrm{RF}$ and hybrid plasma spraying.
徵的である.これは HY 化に伴う粒子速度上昇の結果, 粒子温度が高く，十分溶融した状態で基板に到達できるた めと考えられる.

(2) 溶射皮膜形成

(a) RF プラズマ溶射法による YSZ 皮膜形成

プラズマ作動ガスとして $\mathrm{Ar}-\mathrm{O}_{2}$ 混合ガスを使用した
$\mathrm{RF}$ ，プラズマ溶射法での $\mathrm{RF}$ 入力をパラメーターとした 溶射皮膜の断面 SEM 写真を Fig. 8 に示す. $36 \mathrm{~kW}$ では 入力が低過ぎるため粒子加熱効率が悪く, 溶融状態で基体 に衝突する粒子数が少ないため，形成した皮膜の膜厚が他 の入力と比較して極めて低下していることが分かる。また 入力を増加させた場合，本実験では膜質が良好となること
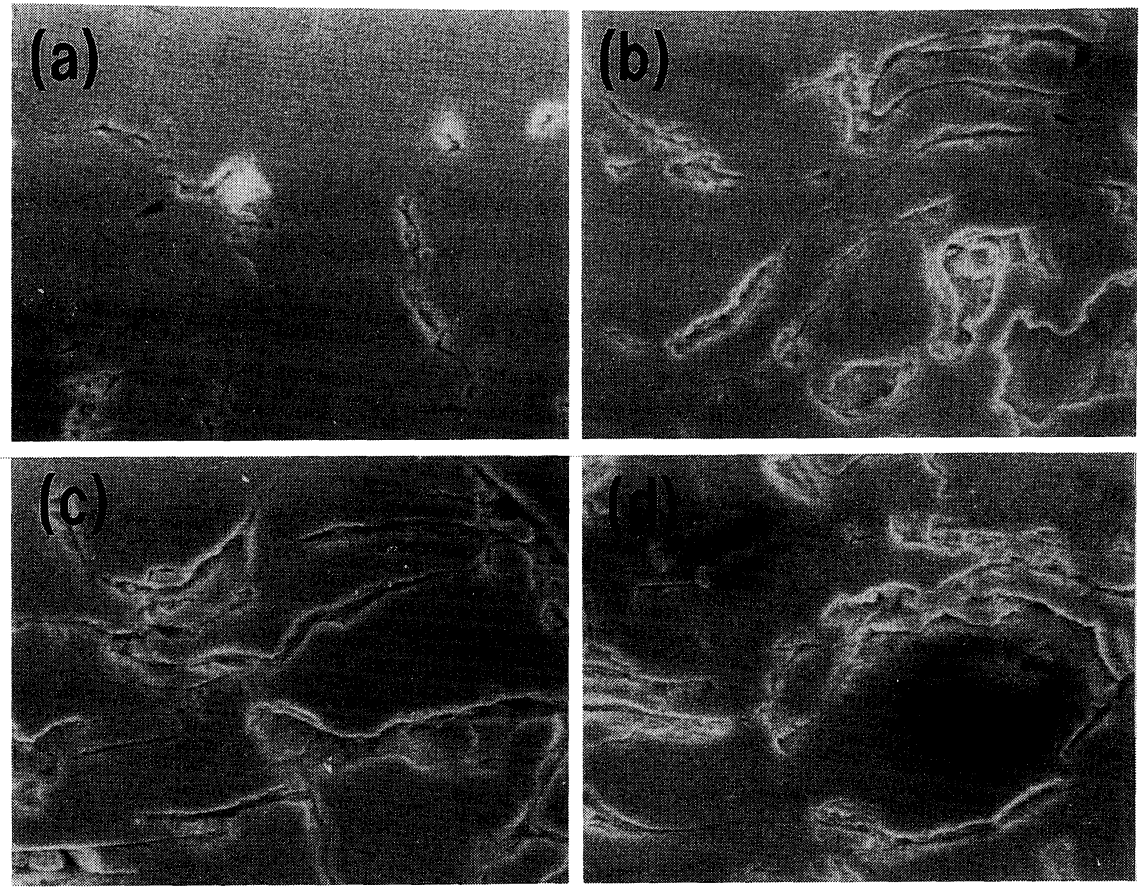

\section{$20 \mu \mathrm{m}$}

Fig. 8 SEM photographs of the cross section of YSZ coatings deposited by $\mathrm{Ar}-\mathrm{O}_{2}$ RF plasma spraying, with different input power.

(a) $50 \mathrm{~kW}$, (b) $46 \mathrm{~kW}$, (c) $40 \mathrm{~kW}$, (d) $36 \mathrm{~kW}$. 


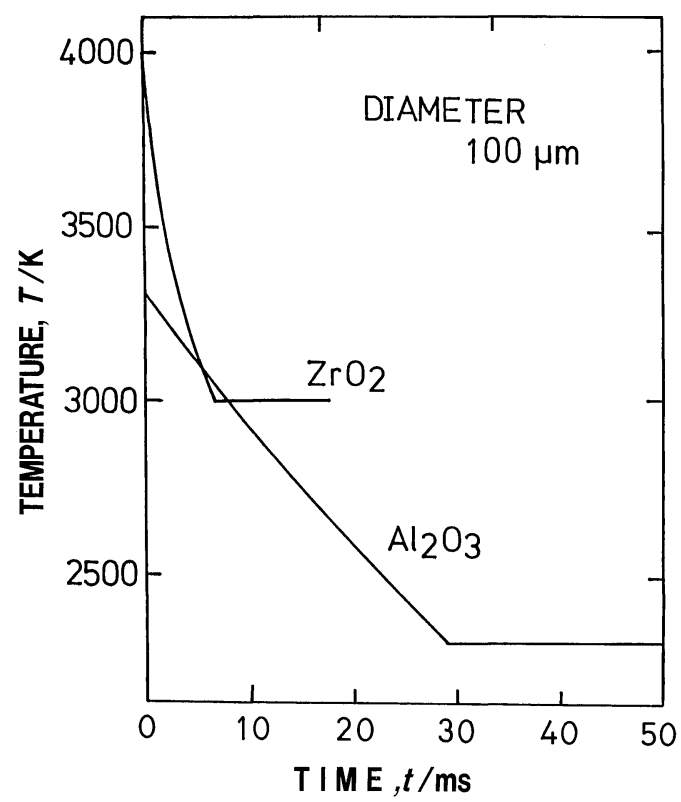

Fig. 9 Solidification step for the cases of $\mathrm{Al}_{2} \mathrm{O}_{3}$ and $\mathrm{ZrO}_{2}$.

を示している。一方，プラズマ作動ガスに $\mathrm{Ar}-\mathrm{O}_{2}$ 系より 熱伝導の高い $\mathrm{Ar}-\mathrm{H}_{2}$ 混合ガスを用いた場合の最高密度は 95\%程度の值を与えた. Fig. 9 に $\mathrm{Al}_{2} \mathrm{O}_{3}$ 乩よび $\mathrm{ZrO}_{2}$ 粒子 の冷却過程の熱の放散を伝導扣よび放射のみによると仮定 した場合の沸点から凝固完了までの温度変化の計算結果 ${ }^{(5)}$ を示す. $\mathrm{Al}_{2} \mathrm{O}_{3}$ と比較して $\mathrm{ZrO}_{2}$ の凝固に要する時間が極 端に短いことが認められる. RF プラズマ溶射ではガスの 低流速性から粒子速度は高々 $20 \mathrm{~m} / \mathrm{s}$ と低く, 凝固完了後 基板に到達する可能性が高い。つまり，本装置レベルの $\mathrm{RF}$ 入力ではプラズマの低流速性が YSZのような高融点 ・高放射率物質の場合, 粒子が基板到達前に一部凝固が開 始してしまい, 緻密化への障害となることが判明した.

\section{(b) HY プラズマ溶射法による YSZ 皮膜形成}

Fig. 10 は各粒径毎の RF プラズマ拉よび HY プラズマ 溶射法による密度測定結果である. 実験条件をTable 1 に示す。図中アーク溶解して作製した試料の密度を BULK 值として表記し, 密度 $100 \%$ とした. RF プラズマ 溶射法では，大粒径粒子 $(88 \sim 105 \mu \mathrm{m})$ の場合溶融が不十 分であるため，また小粒径粒子 $(37 \sim 55 \mu \mathrm{m})$ の場合は蒸発 が激しくなることおよび粒径減少に伴い凝固時間が短縮さ れ，基板到達前に粒子が凝固してしまらため密度が低下す る. 一方, HY プラズマ溶射法では全粒径に括いて密度が 高く，粒径依存性が低いことが特徵となっている．この原 因としては小粒径では粒子速度上昇により過加熱が抑制さ れ，一方大粒径では Hybrid 化により総入力が上がり十分 な溶融が達成されたものと考える．更に如何なる大きさの 粒径をもつ粉末を使用しても，速度上昇に伴い変形度試験

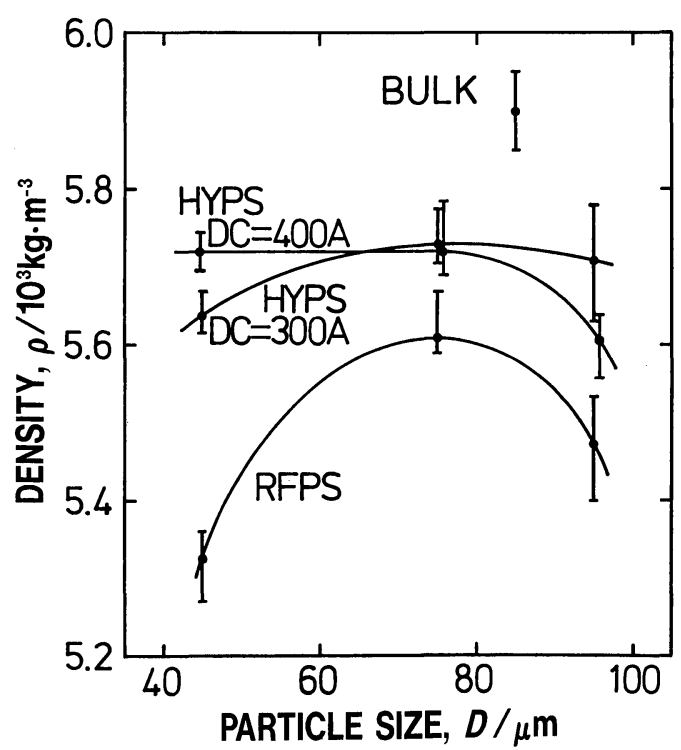

Fig. 10 The effect of YSZ powder size $(d)$ on the coating density for the cases of RF and hybrid plasma spraying.

Table 1 Experimental conditions $\left(\mathrm{ZrO}_{2}\right)$.

\begin{tabular}{|c|c|c|}
\hline \multicolumn{3}{|c|}{ (1) Gas flow rate } \\
\hline & DC jet & $: 1.67 \times 10^{-4} \mathrm{~m}^{3} / \mathrm{s}(\mathrm{Ar})$ \\
\hline & $\mathrm{RF}$ radial sheath gas & $: 5.00 \times 10^{-4} \mathrm{~m}^{3} / \mathrm{s}(\mathrm{Ar})$ \\
\hline & RF tangential sheath gas & $: 5.00 \times 10^{-4} \mathrm{~m}^{3} / \mathrm{s}(\mathrm{Ar})$ \\
\hline & & $: 1.67 \times 10^{-4} \mathrm{~m}^{3} / \mathrm{s}\left(\mathrm{H}_{2}\right)$ \\
\hline & Carrier gas & $: 1.67 \times 10^{-4} \mathrm{~m}^{3} / \mathrm{s}(\mathrm{Ar})$ \\
\hline (2) & Powder condition & \\
\hline & Feeding rate & $: 6.67 \times 10^{-2} \mathrm{~g} / \mathrm{s}$ \\
\hline & Feeding time & $: 120 \mathrm{~s}$ \\
\hline & Powder size & : 37-53, 68-83, 88-105 $\mu \mathrm{m}$ \\
\hline (3) & $\mathrm{RF}$ plate power & : $30-50 \mathrm{~kW}$ \\
\hline (4) & DC power & $: 5-10 \mathrm{~kW}$ \\
\hline
\end{tabular}

結果と同様に十分溶融した状態での基板到達が達成された と考光られる. Fig. 11 は基板位置による断面形状変化の $\mathrm{SEM}$ 写真を示す。緻密な YSZ 皮膜が基板位置に関係な く形成可能なことも判明した. 緻密性を数値化すると, 最 適条件下で密度 $98 \%$ 以上，ガス透過率 $5.7 \times 10^{-7} \mathrm{~cm}^{4} /$ $\mathrm{g} \cdot \mathrm{s}\left(2000 \sim 3000 \mathrm{mmH}_{2} \mathrm{O}\right)$ となり，これらの值は直流プラ ズマ溶射法と比較して, 密度は数\%，ガス透過率は一桁以 上を示し良好な皮膜が形成されることを意味している(6).

他方, 酸素欠損について LECOによる溶射直後および 熱処理後の酸素定量分析を行ったが，Fig. 12 に示すよら に $3 \%$ 以下の酸素欠損が $\mathrm{Ar}-\mathrm{H}_{2}$ のプラズマ作動ガスの場 合認められるが, $1200^{\circ} \mathrm{C}$ 上熱処理によって酸素欠損 は消滅した。また，プラズマ作動ガスに $\mathrm{Ar}-\mathrm{O}_{2}$ 系を用い る場合，酸素欠損の無い皮膜が得られることも確認された。

(3) $\mathrm{LaCoO}_{3}$ 多孔質皮膜形成

SOFCの空気極材として現在有力視されている, 


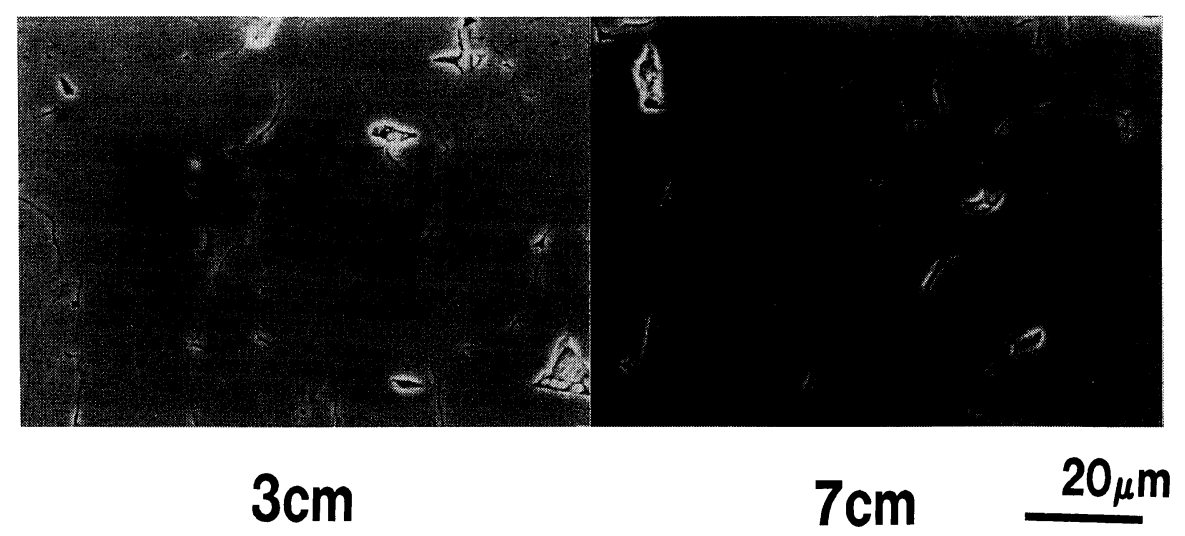

Fig. 11 SEM photographs of the cross section of YSZ coatings sprayed at different substrate positions.

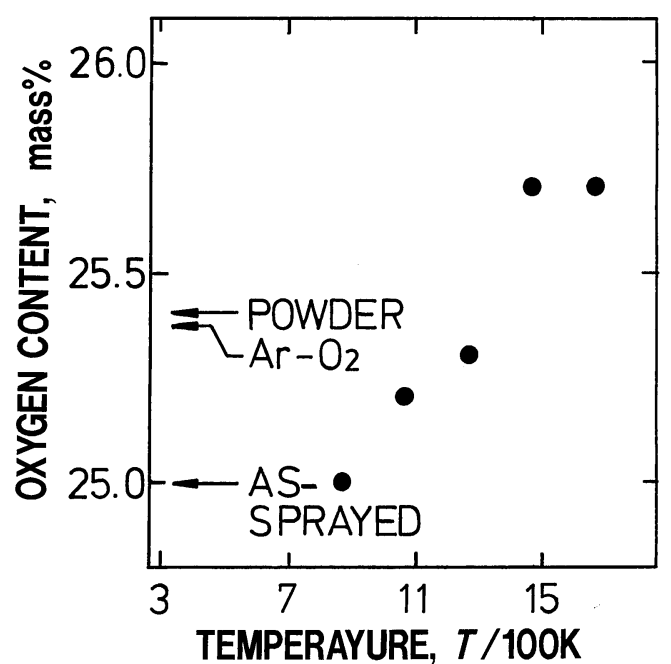

Fig. 12 The effects of thermal treatment temperature on the oxygen content of coatings.
$\mathrm{LaMO}_{3}$ 系のペロブスカイト型酸化物の $\mathrm{HY}$ プラズマ溶射 を検討した。今回はこれらの物質の中で導伝率の最も高い $\mathrm{LaCoO}_{3}$ を用いた. $\mathrm{LaCoO}_{3}$ を $\mathrm{Ar}-\mathrm{O}_{2}$ および $\mathrm{Ar}-\mathrm{H}_{2}$ プラズ マの還元䨌囲気中で溶射した場合の溶射皮膜，扣よび電池 の作動温度 $1000^{\circ} \mathrm{C}$ で大気中 1 時間熱処理後の $\mathrm{XRD}$ 分析結 果をFig. 13 に示す。また実験条件をTable 2 に示す.

Table 2 Experimental conditions $\left(\mathrm{LaCoO}_{3}\right)$.

\begin{tabular}{|c|c|c|}
\hline (1) & Gas flow rate & \\
\hline & DC jet & $: 1.67 \times 10^{-4} \mathrm{~m}^{3} / \mathrm{s}(\mathrm{Ar})$ \\
\hline & $\mathrm{RF}$ radial sheath gas & $: 5.00 \times 10^{-4} \mathrm{~m}^{3} / \mathrm{s}(\mathrm{Ar})$ \\
\hline & $\mathrm{RF}$ tangential sheath gas & $: 5.00 \times 10^{-4} \mathrm{~m}^{3} / \mathrm{s}(\mathrm{Ar})$ \\
\hline & & $: 1.67 \times 10^{-4} \mathrm{~m}^{3} / \mathrm{s}\left(\mathrm{O}_{2}\right)$ \\
\hline & Carrier gas & $: 1.67 \times 10^{-4} \mathrm{~m}^{3} / \mathrm{s}(\mathrm{Ar})$ \\
\hline (2) & Powder condition & \\
\hline & Feeding rate & $: 2.50 \times 10^{-2} \mathrm{~g} / \mathrm{s}$ \\
\hline & Feeding time & $: 600 \mathrm{~s}$ \\
\hline & Powder size & $: 25-88 \mu \mathrm{m}$ \\
\hline (3) & $\mathrm{RF}$ plate power & : $30-50 \mathrm{~kW}$ \\
\hline (4) & DC power & : $5-10 \mathrm{~kW}$ \\
\hline
\end{tabular}

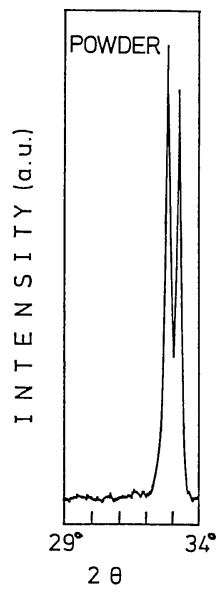

(a)

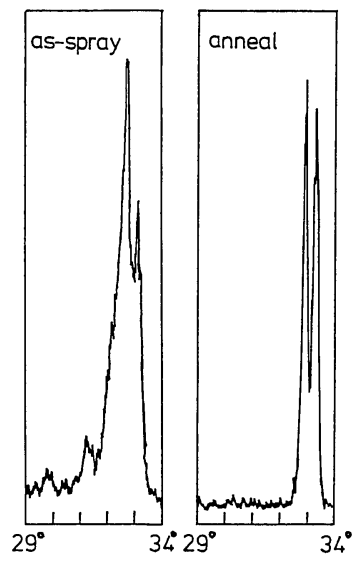

(b) $\mathrm{Ar}-\mathrm{O}_{2}$

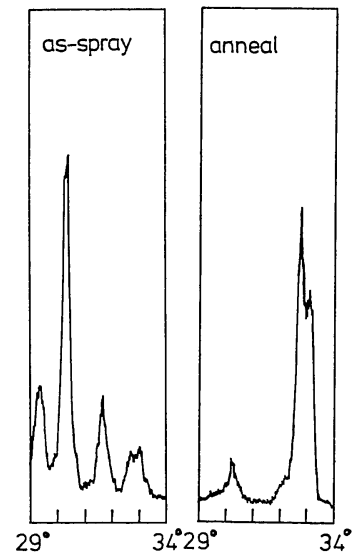

(c) $\mathrm{Ar}-\mathrm{H}_{2}$

Fig. 13 XRD patterns of $\mathrm{LaCoO}_{3}$.

(a) initial powder, (b) coatings sprayed by $\mathrm{Ar}-\mathrm{O}_{2}$ hybrid plasma spraying, (c) coatings sprayed by $\mathrm{Ar}-\mathrm{H}_{2}$ hybrid plasma spraying. (annealing condition: $1000^{\circ} \mathrm{C} \times 1 \mathrm{~h}$ in air ) 

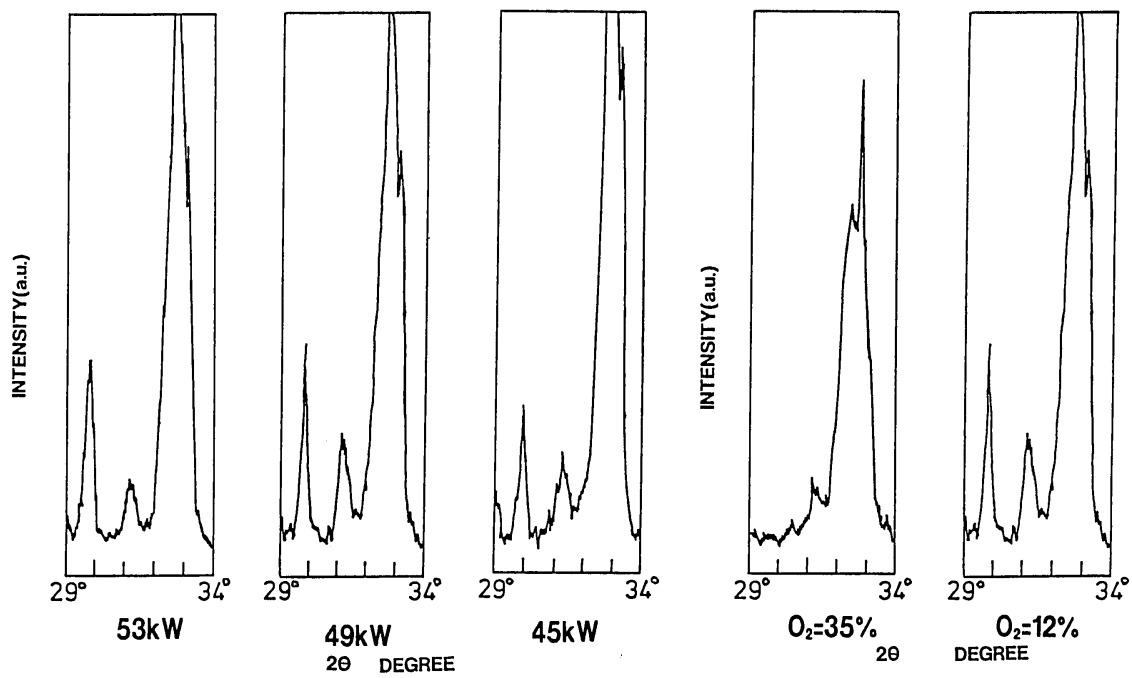

Fig. 14 The effect of total input power and oxygen partial pressure on XRD patterns of sprayed $\mathrm{LaCoO}_{3}$ coatings.

$\mathrm{Ar}-\mathrm{H}_{2}$ の還元雾囲気溶射では皮膜に $\mathrm{La}_{2} \mathrm{O}_{3}$ の存在が認め られた。熱処理後でも $\mathrm{LaCoO}_{3} \cdot \mathrm{La}_{4} \mathrm{Co}_{3} \mathrm{O}_{10} \cdot \mathrm{La}_{2} \mathrm{O}_{3}$ 混晶に なって括り $\mathrm{La}_{2} \mathrm{O}_{3}$ の残留が確認された。 $\mathrm{La}_{2} \mathrm{O}_{3}$ は高温水 素雾囲気下で水素化合物を生成し, 潮解性を呈するため, $\mathrm{SOFC}$ の電極劣化をもたらす．一方 $\mathrm{Ar}-\mathrm{O}_{2}$ プラズマの酸 化雾囲気で皮膜を形成した場合，溶射条件によっては，熱 処理により出発粉体と等しい結晶構造に回復する. Fig. 14 亿総入力括よび冷却用酸素流量を制御した溶射皮膜の $\mathrm{XRD}$ 分析結果を示す。図から $\mathrm{La}_{2} \mathrm{O}_{3}$ の混入を低減させる 条件は, プラズマからの熱伝達を減少させ, 酸素分圧を高 めるものであることが分かる.

これらの結果の解釈として, 高温領域で酸素分圧を变化 させた場合, Fig. 15 の La-Co-O 系の自由エネルギー図に 示すよらに $\mathrm{LaCoO}_{3}$ は $\mathrm{La}_{4} \mathrm{Co}_{3} \mathrm{O}_{10} \rightarrow \mathrm{La}_{2} \mathrm{CoO}_{4} \rightarrow \mathrm{La}_{2} \mathrm{O}_{3}$ に分 解する、溶射法が液相を利用するプロセスであるため粒 子温度を一旦融点 $(2500 \mathrm{~K})$ 以上に加熱する必要があり, $\mathrm{La}_{2} \mathrm{CoO}_{4}$ までの分解は避けられない. 更に溶射法では粒 子の凝固速度が $10^{4} \mathrm{~K} / \mathrm{s}$ 以上の急冷凝固プロセスであるこ とを考慮すると高温安定相が形成されることもある程度避 けられない。しかしながら $\mathrm{La}_{2} \mathrm{O}_{3}$ までの分解掞よび $\mathrm{CoO}$ のCoへの還元は酸素分圧を制御することにより可能であ ると考えられる. 実際本研究に扮いて酸素分圧を高めるこ とにより $\mathrm{La}_{2} \mathrm{O}_{3}$ までの分解は抑止可能となった．この 2 つの反応によって生成する $\mathrm{Co}$ と先の $\mathrm{CoO}$ の蒸気圧を比 較した場合, $\mathrm{Co} の$ 蒸気圧は $\mathrm{CoO}$ と比較して 1 析〜2 桁高 $<\mathrm{La}_{2} \mathrm{CoO}_{3}$ の融点近傍では 10 Torr 以上になり, 酸素分 圧が低い場合には Co 原子が蒸発し皮膜内の $\mathrm{La}$ と Co の モル比の变化が生じる. このようにCo が減少したことに より, $\mathrm{Ar}-\mathrm{H}_{2}$ 系溶射膜では熱処理後の膜内にも $\mathrm{La}_{2} \mathrm{O}_{3}$ が 残留したものと考兄られる. DC プラズマ溶射法ではプラ ズマ内部の酸素分圧制御は極めて困難であると考学られ，

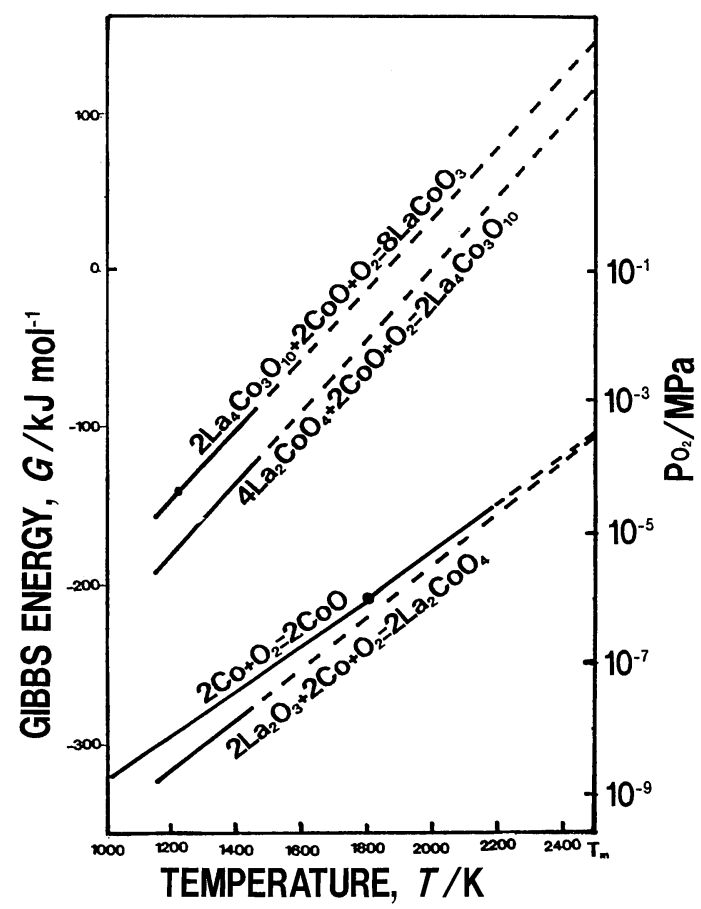

Fig. 15 Ellingham diagram of La-Co-O system.

今後更に検討の余地はあるが，高温で化学的に分解し易い 酸化物の溶射に扣いて通常の直流プラズマ溶射法に対し て, 高酸素分圧下での溶射が可能な RF および $\mathrm{HY}$ プラ ズマ溶射法の利点が示された.

\section{(4) SOFC の一貫作成}

最後に SOFC の一貫作成に必要とされる溶射法の多層 コーティングへの適応について検討した. 多層コーティン グは電池の構造に合わせ, 多孔質 CSZ 円筒基板上に 


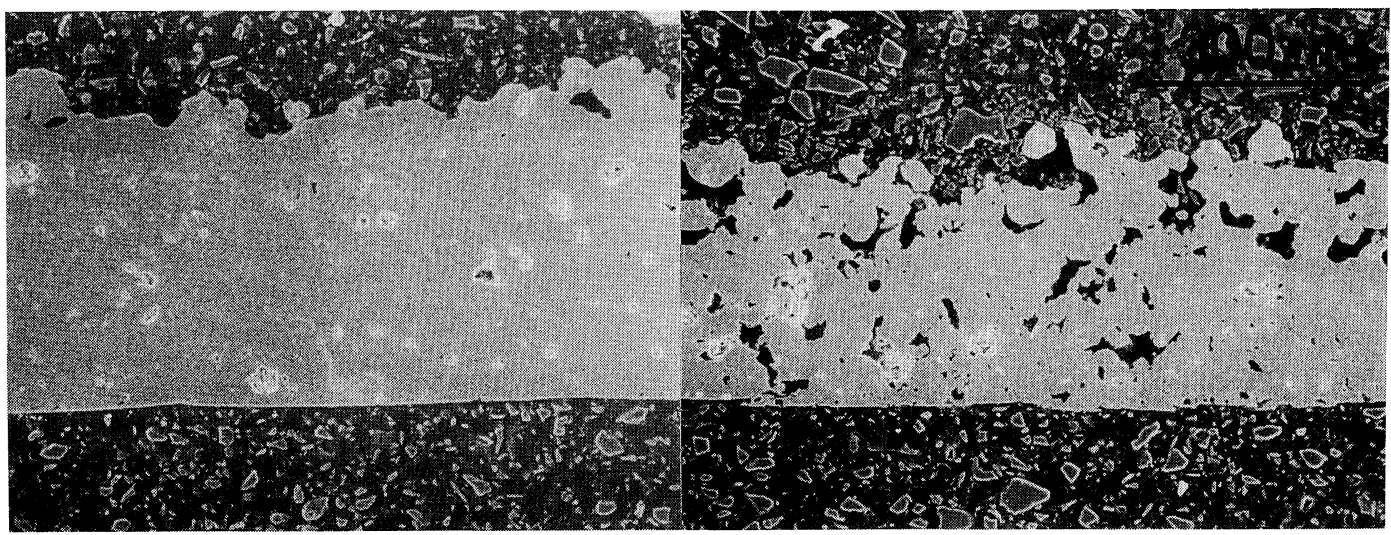

(a)

(b)

Fig. 16 SEM photographs of the cross section of $\mathrm{NiO}$ coatings deposited by hybrid plasma spraying at the substrate position, $140 \mathrm{~mm}$.

(a) without gas coolong. (b) with gas cooling.

$\mathrm{NiO} \rightarrow \mathrm{YSZ} \rightarrow \mathrm{LaCoO}_{3}$ の順で行った。先述の通り $\mathrm{NiO}$ と $\mathrm{LaCoO}_{3}$ には多孔質化が，また $\mathrm{YSZ}$ には緻密化が要求さ れている. Fig. 16 は溶射中基板上への粒子冷却ガスの影 響を示した $\mathrm{NiO}$ の断面形状 SEM 写真である．冷却ガス 噴射により多孔質化が顕著認められた。次に先の実験か ら得られた $\mathrm{YSZ}$ と $\mathrm{LaCoO}_{3}$ の最適条件で順次溶射を行っ た. Fig. 17 はY プラズマ溶射法で連続溶射した上記三 層の断面 SEM 写真执よび EDX 分析によるX 線マップで
ある．この写真から $\mathrm{NiO}$ 層の多孔性が崩れていることが 分かる.これは, YSZ の皮膜堆積時のプラズマ作動ガス に $\mathrm{Ar}-\mathrm{H}_{2}$ を用いたため $\mathrm{NiO}$ が低融点の $\mathrm{Ni}$ 飞還元し溶融 したためである.しかし，YSZ 溶射に拈けるプラズマ作 動ガスに $\mathrm{Ar}-\mathrm{O}_{2}$ を用い $\mathrm{NiO}$ の還元抑制や基板の高速移動 による局所加熱抑制などによりこの問題点は解決できると 考兄られる。また， $\mathrm{YSZ}$ と $\mathrm{LaCoO}_{3}$ の界面に割れが確認 され，多層溶射に淤ける界面制御は今後の課題として残さ

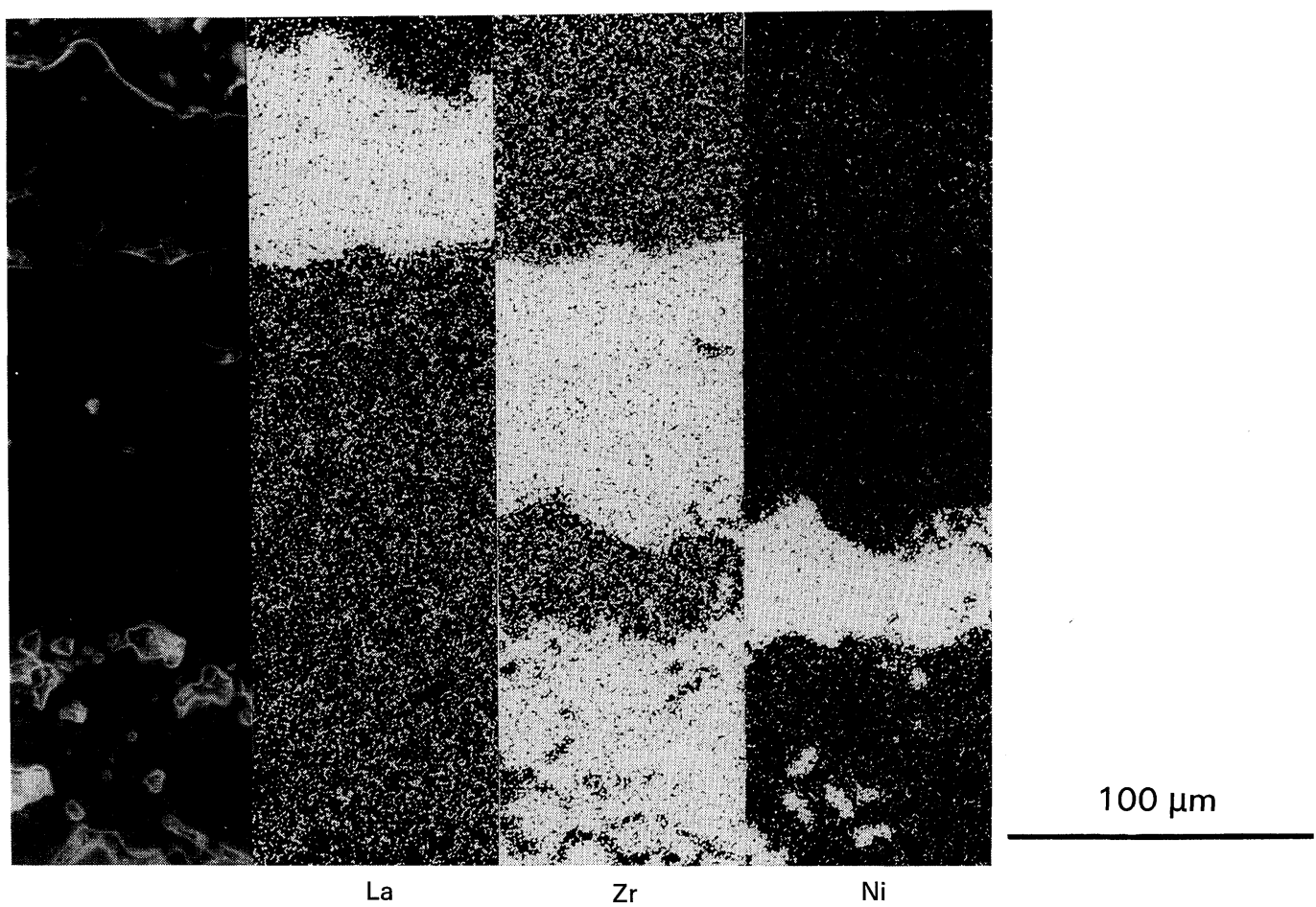

Fig. 17 The cross sectional SEM and X-ray images of La, $\mathrm{Zr}$, Ni of the triple-layered coating deposited by hybrid plasma spraying on a pourous $\mathrm{ZrO}_{2}$ substrate. 
れた。

\section{III. 考察}

一般に溶射に括ける膜質は以下の指針により制御可能と なる. (1)入力, 粒径, 粒子速度, 粉体供給量を変化させ, プラズマを通過する粒子 1 個当りに伝達されるェネルギ 一を制御する. (2)粒子速度，プラズマ高温領域通過後の空 間冷却能を变化させ，冷却過程を制御する。.の2 点であ る. 当然その前提としては各粒子の “均一な熱履歴”が極 めて重要な因子であるが，序論で述べたように均一加熱は $\mathrm{RF}$ 拉よび HY プラズマ溶射法の DC プラズマ溶射法に比 する大きな利点である。

粒子速度測定結果から，YSZ 粒子のプラズマ尾炎部の 冷却空間通過時間は HY プラズマ溶射では約 $1 \sim 2 \mathrm{~ms}$, $\mathrm{RF}$ プラズマ溶射では約 $5 \mathrm{~ms}$ と算定できる。一方飛行粒 子 $(100 \mu \mathrm{m})$ が怙もに放射により冷却すると仮定すると沸 点近傍 $(T=4000 \mathrm{~K})$ から融点凝固開始までの時間は約 5 $\mathrm{ms}$ である。つまり両手法による粒子変形度, 皮膜密度の 差は，HY プラズマの導入により，粒子速度が上がり凝固 完了前に基板到達が可能となったこと，拉よび DC 入力増 加に伴い総入力が増加し，粒子の十分な溶融が達成され， 基板位置や粒径の依存性が低下したことに起因寸ると考兄 られる，すなわち，HY プラズマ溶射は DC 入力を変える ことにより粉体の初期速度制御をある程度可能とし， RF プラズマと DC プラズマ入力のバランスおよび総入力を調 整することにより膜質コントロールを可能とする新しい溶 射プロセス技術であると言兄る．溶射法に执いて緻密皮膜 形成が最も困難とされている YSZ で相対密度 $98 \%$ の值を 示したことは，本手法で液相を持つほとんどの物質の膜質 制御が可能であることを意味する.

$\mathrm{Ar}-\mathrm{H}_{2}$ 雾囲気中で形成した YSZ 皮膜は灰色から黒色を 呈して括り，分析からも酸素欠損を認めた．SOFCへの適 用に際する影響としては酸化雾囲気での膜内応力分布変化 による割れや電気的特性変化をもたらす可能性がある。し かし， $\mathrm{Ar}-\mathrm{O}_{2}$ 护よび $\mathrm{Ar}-\mathrm{H}_{2}$ プラズマ雾囲気で得られた YSZ 皮膜の XRD 分析結果から導出した格子定数に特に 差異は認められず，上記酸素欠損に起因する応力的問題は 殆どないと考光られる。仮に電気的特性と併せて, $\mathrm{Ar}-\mathrm{H}_{2}$ 雾囲気が問題となったとしても $\mathrm{Ar}-\mathrm{O}_{2}$ 系の導入によりこ の点を解決することは容易であると結論づけられる。

HY プラズマ溶射法は粒子速度の独立制御が可能である ことが RF プラズマ溶射法と比較しての利点であるが，装 置的に複雑となるため RF プラズマ溶射法の適用可能な場 合にはより実用的である。しかしながら実験室レベルの $\mathrm{RF}$ 入力では上述のように粒子の低速性から YSZ の緻密 化は不可能であった．RF プラズマ溶射法でYSZ の緻密 皮膜形成を達成するには更に高出力 $\mathrm{RF}$ 酸素プラズマでの
溶射または粒子速度の高速化のため減圧下での溶射を適用 することによって可能となると考えられる.

$\mathrm{LaCoO}_{3}$ は高温で分解し易く, プラズマ溶射法にとっ $\tau$, 高温領域で化学的に不安定な物質の皮膜形成の例とし て代表的な材料であると言える．DCプラズマ溶射法に拉 いてはこの物質の皮膜形成の報告例は少なく，国内では電 子総合研究所が $\mathrm{CoO}$ を添加して皮膜形成に成功している が，完全な $\mathrm{LaCoO}_{3}$ でないため導伝率が70 80\%程度に 低下寸ると言われている。このような物質を安定に堆積さ せることが可能となれば，溶射法の新しい応用範囲が見 いだせることになる.SOFCの空気電極としては $\mathrm{La}_{x} \mathrm{Sr}_{1-x} \mathrm{MnO}_{3}$ が最有力で研究段階であるが本法による雾 囲気制御により皮膜の安定化は容易であると考兄られる。 更に SOFC としては多層皮膜コーティングの界面強度を 改善するためには膜質に傾斜をつけることや新たな物質探 索が必要と考兄られる。

\section{N. 結 論}

（1） HY プラズマ溶射法では RF プラズマ溶射法と比較 して，粒子速度は $2 \sim 3.5$ 倍上昇した. この粒子速度を制 御することにより従来の DC プラズマ溶射法では不可能で あった YSZ の緻密皮膜(相対密度 $98 \%$ )が形成された。

（2）酸素分圧拉よび総入力を制御し，熱処理を施すこと により DC プラズマ溶射法では極めて困難であると考えら れる $\mathrm{LaCoO}_{3}$ 安定皮膜形成が本手法により可能であること が判明した。

（3）技術的問題点は残するのの上記 SOFC の一貫作成 例によりプラズマ溶射法の高機能性材料・傾斜材料等の新 たなる応用分野への適用の可能性が示された。

本研究の粒子速度計測に扣きうて, 東京大学工学部総 合試験所高速度カメラ室の津野隆夫助手，中村美雄技官に ご協力いただきました。また，本研究の一部は科学研究費 エネルギー重点領域研究(課題番号02203211)の補助を受 けました。ここに記して感謝いたします。

\section{文献}

（1）竹内 順，岡田知久, 吉田豊信，明石和夫：日本金 属学会誌, 52(1988), 711.

(2) T. Okada, H. Hamatani and T. Yoshida: J. Amer. Ceram. Soc., 72(1989), 2111.

( 3 ) S. D. Savkar and P. A. Siemer: Proc. Workshop on Indual Plasma Applications, Pugnochiuso, Italy, (1989), 80.

(4) H. Hamatani, T. Okada and T. Yoshida: Proc 9th ISPC, Pugnochiuso, Italy, (1989), 1527.

（5）浜谷秀樹：修士論文，東京大学，(1990)。

(6) H. Arai: Proc. Int. Symp. on Solid Oxide Fuel Cells, Science House Co., Ltd., Tokyo, (1989), 12. 